\title{
SISTEMAS CULINÁRIOS AFRO-BRASILEIROS AS BAIANAS DE ACARAJÉ DO RIO DE JANEIRO
}

Nina Pinheiro Bitar (UFRJ)

O objetivo deste artigo é problematizar a categoria baiana de acarajé no contexto do Rio de Janeiro, através da descrição e análise da forma pela qual esses agentes se constituem. A partir da pesquisa de campo, procuro traçar as histórias de vida de quatro baianas de acarajé. Assim, busco compreender os múltiplos significados da baiana e de seu acarajé, através do sistema culinário em que estão inseridos.

SISTEMAS CULINÁRIOS, DÁDIVA, PATRIMÔNIO, ESPAÇO PÚBLICO, RELIGIÕES AFRO-BRASILEIRAS, RIO DE JANEIRO. 


\section{INTRODUÇÃO}

O presente artigo é resultado da pesquisa desenvolvida em 2008 e 2010 (BITAR, 2011), na qual refleti sobre a formação da categoria baiana de acarajé no contexto da cidade do Rio de Janeiro. Procurei entender o processo de tornar-se baiana de acarajé, através do acompanhamento do cotidiano de três baianas e um "baiano" de acarajé, desde a escolha dos ingredientes, o preparo, a venda e o desfazer dos restos, além de outros contextos informais, longe dos tabuleiros.

Alguns poucos trabalhos abordam a temática da atuação das "baianas" no Rio de Janeiro. Destaco os trabalhos de Moura (1995) sobre a famosa baiana Tia Ciata; de Velloso (1990) a respeito das "tias baianas" que atuaram nesta cidade e de Rocha (2007), que aborda as baianas na iconografia de Cecília Meireles. Sobre as baianas de acarajé de Salvador, Martini (2007) analisa a dimensão histórica da construção dessa categoria nesse contexto; Dias (1985) é importante referência para o estudo das "negras de tabuleiro" de São Paulo; Lody $(1998 ; 2002)$ vem realizando trabalhos sobre a comida das religiões afrobrasileiras; o antropólogo Lima (2005) desenvolve significativos estudos sobre as religiões afro-brasileiras, os quais abordam as "comidas de santo"; Querino (1954) foi precursor dos estudos sobre culinária baiana. E não podemos deixar de citar História da alimentação no Brasil (CASCUDo, 1983).

Uma das ideias centrais que permeia este estudo é o entendimento da comida como integrante de um sistema culinário. Pode-se dizer que tal concepção apreende a comida enquanto parte de um conjunto social e cultural, enfatizando as relações sociais e simbólicas em que ela está inserida e nas quais desencadeia efeitos. A perspectiva de sistema insiste sobre a pluralidade e a interdependência de seus elementos constituintes, os quais vão desde a classificação e obtenção do alimento (quem compra e com quem, o que é considerado um bom ou ruim ingrediente para ser consumido, ou seja, como são feitas essas escolhas); seu preparo; a disposição de seus restos, ou como é fechado esse ciclo e reiniciado. (GONÇALVES, 2007; MAHIAS, 1991; VERDIER, 1969). São conjuntos de práticas e representações fortemente integrados a determinadas cosmologias, que unem pessoa, sociedade e universo (GONÇALVES, 2002). A partir desse instrumental analítico apreendo os significados sociais e simbólicos atribuídos à comida em contextos diferenciados.

Outra questão importante a ser destacada é a opção pelo uso do termo "comida" e não "alimento". Na perspectiva da diferenciação entre fome e paladar, podemos problematizar e qualificar os usos das palavras "comida" e "alimento" (GONÇALVES, 2004; 2007). É possível dizer que a categoria "alimento" aparece como uma resposta à fome, um representante da falta, no plano fisiológico, de uma suposta experiência humana universal; "comida" é associada ao paladar (ou gosto) e aparece como o que diferencia e constitui culturas, coletividades e indivíduos, possuindo temporalidade própria.

A pesquisa também teve como objetivo discutir o processo de registro do "ofício das baianas de acarajé" como "patrimônio imaterial", realizado pelo Instituto do Patrimô- 
nio Histórico e Artístico Nacional - Iphan em 2004. Nesse sentido, problematizei a categoria "patrimônio", formulada tanto pelas baianas de acarajé quanto pelas políticas públicas de registro de "bens imateriais".

Participaram da pesquisa Sônia Baiana; Baiana Ciça; Jay do Acarajé; e Nicinha. Todos nasceram na Bahia e no período da realização da pesquisa trabalhavam no Rio de Janeiro. Apesar das diferenças entre as baianas e o baiano de acarajé estudados, foi recorrente fazerem ligação entre acarajé e religiões afro-brasileiras. Até mesmo no processo de registro do "ofício das baianas de acarajé" pelo Iphan, é ressaltada essa origem.

Consequentemente, busquei compreender como é o dia a dia de tais baianas e como entendem a categoria patrimônio em termos nativos. Também foram analisadas as implicações de ser baiana de acarajé na cidade do Rio de Janeiro, e como se articulam ao "ofício das baianas de acarajé", registrado pelo Iphan (BITAR, 2011). Assim, pode-se dizer que o registro realizado pelo Iphan dessa atividade constitui um evento (SAHLINS, 2004) produzido e reelaborado pelas baianas de acarajé aliadas às políticas públicas.

\section{APRESENTAÇÃO}

O pedido de registro do "ofício das baianas de acarajé" como "bem imaterial" foi proposto pela Associação das Baianas de Acarajé, Mingau, Receptivos e Similares - Abam, pelo Terreiro llé Axé Opô Afonjá e pelo Centro de Estudos Afro-Orientais da Universidade Federal da Bahia - Ceao. ${ }^{1}$ Foi inscrito no Livro dos Saberes do Patrimônio Imaterial como "patrimônio cultural brasileiro" em 2004. ${ }^{2}$

Aqui temos como proponentes do registro a conjugação de uma associação civil que organiza as baianas de acarajé; um centro de estudos da Faculdade de Filosofia e Ciências Humanas da Universidade Federal da Bahia; e um terreiro de candomblé tombado pelo Iphan em $2000,{ }^{3}$ no qual, aliás, o então ministro da Cultura Gilberto Gil foi "iniciado". O primeiro passo da pesquisa foi pensar por que, em um dado momento, se registrou tal "ofício".

Para entender essa questão, em 2008 entrevistei na sede
1. "O Centro de Estudos Afro-Orientais (Ceao) é um órgão suplementar da Faculdade de Filosofia e Ciências Humanas da Universidade Federal da Bahia voltado para o estudo, a pesquisa e ação comunitária na área dos estudos afro-brasileiros e das ações afirmativas em favor das populações afro-descendentes, bem como na área dos estudos das línguas e civilizações africanas e asiáticas." in www.ceao.ufba.br/2007/ apresentacao.php (acesso: jan. 2010).

2. Dados do processo: Pedido de Registro aprovado na 45a reunião do Conselho Consultivo do Patrimônio Cultural, em 01.12.2004. Inscrição no Livro dos Saberes em 21.12.2004.

3. Pode-se dizer que o registro do "ofício das baianas de acarajé" faz parte de um processo mais amplo de políticas de reconhecimento de "bens culturais" afrodescendentes. Para uma discussão sobre os tombamentos de terreiros em Salvador, ver Gomes, 2009. Consultar também Sansi-Roca (2007) sobre as transformações do valor museográfico dos objetos das religiões afrobrasileiras. da Associação a presidente da Abam, Rita, que revelou ser a atual reivindicação das baianas de acarajé o reconhecimento dessa atividade como profissão, uma vez que agora já é reconhecida como patrimônio pelo Iphan. Ela afirmou que não gostaria de continuar 
preenchendo o campo profissão como cozinheira, mas, sim, como baiana de acarajé, explicando que "cozinhar, eu cozinho em casa". Em sua opinião, o local de atuação dessa profissão é a rua. Pode-se dizer que a dimensão pública e performativa da atividade das baianas de acarajé, desde o início da pesquisa, com essa fala da presidente, se tornou questão importante a ser acompanhada no cotidiano das baianas de acarajé.

O chamado "ponto", local de venda do acarajé, é fundamental para essas baianas de acarajé, e "fazer o ponto" revelou-se procedimento complexo e muitas vezes não bem-sucedido. Foi possível observar, a partir da pesquisa, que fazer o ponto envolve desde relações com a Prefeitura local (para a legalização desse trabalho informal), até a conquista de clientela e relações com entidades das religiões afro-brasileiras.

Neste estudo reflito sobre as relações entre pessoas e objetos focalizando o "mundo" das baianas (SCHUTZ, 1945; BECKER, 1977). A perspectiva de "mundo" é a de pensar as diferentes relações e cadeias de atores que envolvem, no caso, as atividades das baianas. Descrevo os múltiplos significados das baianas e dos

4. Segundo o Ministério do Trabalho e Emprego, "A economia solidária vem se apresentando, nos últimos anos, como inovadora alternativa de geração de trabalho e renda e uma resposta a favor da inclusão social. Compreende uma diversidade de práticas econômicas $e$ sociais organizadas sob a forma de cooperativas, associações, clubes de troca, empresas autogestionárias, redes de cooperação, entre outras, que realizam atividades de produção de bens, prestação de serviços, finanças solidárias, trocas, comércio justo e consumo solidário". http://www.mte. gov.br/ecosolidaria/ecosolidaria_oque.asp (acesso: 16. nov. 2009). objetos, e observo como agem. Abordo uma pequena parte desse "mundo" das baianas de acarajé através da perspectiva de atos e declarações performativas na esfera pública. A sequência de apresentação obedece à de meu contato com elas.

Percebi, ao longo do trabalho de campo, que as baianas narravam sua vida a partir de sua interação com a comida que produzem; marco em sua vida, é a partir dessa relação que constroem a narrativa sobre sua trajetória pessoal. Era em relação a seu trabalho com esse produto que explicitavam os caminhos que suas vidas tomaram e as escolhas que fizeram. Assim, essas histórias foram constituídas de uma forma específica, através da ligação das baianas com o acarajé. Falando a respeito desse objeto, sua origem, o significado dessa comida, estavam também falando sobre si. Interagindo cotidianamente com o acarajé (e com a rede de objetos por ele articulada, como os ingredientes e as roupas), formavam-se simultaneamente como baianas de acarajé. Trata-se, portanto, de processo tanto metafórico, em que o acarajé significa algo e representa algo, quanto metonímico, posto que as baianas ao fazer e vender o acarajé de determinada forma, se constroem.

Através desse viés, o acarajé aparece como desafio no sentido de buscar entender o motivo pelo qual essa comida especificamente, e não outra qualquer, é escolhida e, com isso, que

valor assume. Pode-se dizer que há extensa rede social e simbólica envolvendo as baianas de acarajé, em que os objetos que as constituem não podem ser separados de sua noção de pessoa. 
A primeira baiana que conheci foi Sônia Baiana, que tem ponto de venda de acarajé na Feira de Antiguidades da Rua do Lavradio, no Centro do Rio de Janeiro. Morando há 20 anos na cidade, Sônia fez seu ponto a partir de sua relação com o movimento negro, através de cursos de capacitação na Incubadora Afro-Brasileira e do projeto de Economia Solidária. ${ }^{4}$ Assim, seu círculo de relacionamentos envolve pessoas que trabalham com a temática afro, da qual ela se afirma representante em função da venda do acarajé, da culinária afro.

Sônia relaciona a origem do acarajé à África, diferente das outras baianas, que vinculam essa comida às religiões afro-brasileiras. Ela busca a valorização da cultura afro: sonha em promover cursos de capacitação, nos quais ensinaria não só como fazer o acarajé, mas o que significa o turbante, a roupa e os outros elementos, já que todos são dotados de significado mais amplo que, segundo Sônia, estão relacionados à noção de etnicidade.

A Baiana Ciça há dez anos mora no Rio de Janeiro e fez seu ponto na Rua do Mercado, na esquina da Praça XV de Novembro, também no Centro da cidade. Ao narrar para mim como escolheu seu ponto de venda, relatou que foi levada pelos santos Cosme e Damião, ${ }^{5}$ para os quais, até hoje, paga a promessa de distribuição de comida na Praça XV no dia desses santos, 27 de setembro. Seu ponto revelou-se local de encontro do povo de santo, pessoas relacionadas às religiões afro-brasileiras. Ciça promove, ao longo do ano, além de sua promessa a Cosme e Damião, a lavagem da Rua do Mercado, no Centro do Rio de Janeiro, antes do carnaval; o almoço de Sexta-Feira Santa, em sua casa; e o Festival de Acarajé da Baiana Ciça, no Clube Internacional de Regatas, no Centro da cidade, em outubro.

Pode-se ver, à frente de seu ponto, o Chafariz de Mestre Valentim e o Paço Imperial. Ao lado, encontra-se o Arco do Telles, o qual dá acesso à Travessa do Comércio até a Rua da Lapa dos Mercadores. Muitos de seus clientes são pessoas que trabalham e estudam no Centro ou ainda os moradores de Niterói que passam por lá para chegar à Estação das Barcas, também próxima. Seu "público" é formado pelas pessoas que estão no Centro da cidade, geralmente a trabalho, mas que encontram em seu ponto um refúgio em meio ao ritmo acelerado que caracteriza essa região.

Observei, ao longo do trabalho de campo, que os clientes são seus amigos, guardando respeito por ela. Chamam-se mutuamente de "mãe", "pai", etc. Ela diz "cadê o meu menino?", perguntando sobre o paradeiro de alguém de quem gosta. Ciça é filha de lansã e diz que lansã adora acarajé. Sempre que seus clientes vão embora, diz: "que lansã lhe proteja", "muito axé".

BITAR, Nina Pinheiro. Sistemas culinários afro-brasileiros 
6. Disponível no site: www.misterofacaraje. com/principal.html (acesso: 25 nov. 2009).
O baiano pesquisado, Jay do Acarajé, vive há três anos no Rio de Janeiro e não conseguiu ainda a legalização de seu ponto junto à Prefeitura. Provisoriamente, instala-se na Rua Siqueira Campos, em Copacabana. Ele narra, em seu blog, ${ }^{6}$ as dificuldades de ser baiano de acarajé na cidade. Fugir do rapa (guar-

das municipais) e ter que morar nas ruas foram algumas de suas rotinas como baiano de acarajé.

Jay relatou ter trabalhado durante dez anos com acarajé em Capelinha, Salvador, e que aprendeu a cozinhar com a família, pois sua tia e sua mãe vendiam acarajé. Ele, de certa forma, se decepcionou com seu trabalho na cidade do Rio de Janeiro. Informou que saiu de Salvador por trabalhar em uma periferia pobre, onde as pessoas não conseguiam pagar o valor de seu trabalho, pois lá não havia público para pagar o produto caro que vendia. Conheceu o Rio de Janeiro através de turismo, e resolveu morar na cidade, onde, inicialmente, não trabalhou com acarajé. Seu primeiro ponto de venda de acarajé foi na orla da Praia de Ipanema, próximo à Rua Farme de Amoedo. Como não tivesse autorização, teve que sair de Ipanema e transferir o ponto para a Rua Siqueira Campos, perto da Rua Barata Ribeiro, em Copacabana. Posteriormente, viu-se novamente obrigado a mudar o ponto, localizando-se na mesma rua, mas na esquina da Praça Serzedelo Correia. Atualmente, ele mora nesse mesmo bairro.

Afirma estar perpetuando uma tradição e considera que precisaria haver incentivo da Prefeitura para ter uma baiana em cada esquina. Mas tradição, para ele, tem sentido particular. Quando começou a fazer acarajé, explica, diferenciou-se das baianas "mais velhas" por ter "paladar de jovem" que, em sua opinião, se diferencia da "comida de veIho", uma comida sem sabor, sem tempero e sem sal. O paladar jovem, próximo ao que o público pede, pressupõe gosto mais forte da comida mais temperada. Então começou a vender acarajé através de uma proposta de inovação no paladar.

Sua principal queixa é a de ser tratado como "ambulante" e ter que fugir dos guardas municipais. Diferente das outras baianas incluídas na pesquisa, Jay, por ter situação instável, utiliza como tabuleiro uma "carroça" (como ele denomina): é móvel, de quatro rodas e assemelha-se à carroça utilizada para o comércio de pipoca, tapioca ou cachorro-quente.

Ser baiano de acarajé, para Jay, é também fazer parte de uma tradição mais ampla, um contexto maior, que o fez aprender a ser baiano e a comercializar o acarajé, já que, como disse, não se aprende a fazer acarajé como "receita de bolo". Integrando uma tradição familiar e baiana, Jay ressalta, por outro lado, as inovações que promove, como a "MacEmbalagem" e o "Bará", uma espécie de abará (massa de acarajé cozida geralmente em folha de bananeira) com recheios diferenciados dos usuais, invenção sua, revelando forma particular de relação com o mercado e com a tradição da preparação e venda do acarajé.

Nicinha foi a primeira baiana de acarajé a ter barraca na Feira Hippie de Ipanema, na qual trabalha há 40 anos. Foi indicada por um pai de santo que conheceu as baianas 
"antigas" do Rio, como Esmeralda, sua mãe, já falecida. Nicinha revelou ampla rede de parentesco entre baianas que vieram para a cidade na década de 1940, bem como uma forma de fazer o ponto ligada ao processo de migração. Assim como sua mãe, Esmeralda, Nicinha é ekedi ${ }^{7}$ de Obaluaiê, orixá que traz doenças e que também as cura de uma forma geral, que é o "dono da barraca".

Esmeralda chegou ao Rio de Janeiro na década de 1940 e residiu na antiga Favela do Esqueleto, onde está localizada hoje a Universidade Estadual do Rio de Janeiro - Uerj, local então sensivelmente habitado por migrantes baianos. Vendia acarajé na Praça Saens Peña, no bairro da Tijuca, Zona Norte.

A baiana Nicinha ajudava a mãe na Praça Saens Peña e, posteriormente, na Feira Hippie de Ipanema, ponto que herdou e no qual trabalha há 40 anos, tempo, aliás, de existência da feira. Ela lembra que, quando ela e Esmeralda foram para essa feira, havia apenas poucas pessoas vendendo, com produtos em cima de panos no chão. Hoje, diz, as coisas estão diferentes, é preciso cumprir certas regras de vigilância sanitária, o que na época de sua mãe não era necessário, como, por exemplo, separar as comidas que levam em caixas de isopor com gelo. Assim, elas tiveram que se adaptar a essas mudanças nas concepções de higiene, formando uma espécie de restaurante de rua, com estrutura diferente de outros tabuleiros já analisados. Também têm que assinar ponto em cada domingo de trabalho, não po-

7. "Zelador dos orixás, quando eles descem nas filhas; acolita" (FONSECA JUNIOR, 1995). Todos OS termos em iorubá foram consultados nesse dicionário, indicado por meus interlocutores filhos de santo. Assim, trato o dicionário também como um discurso nativo. Não entrarei na discussão já traçada sobre as diferenciações entre as chamadas "nações" de candomblé. Minha escolha da terminologia iorubá foi decorrência do maior contato com interlocutores que frequentavam a barraca de Ciça, que utilizavam essa língua. dendo faltar. Precisam, enfim, cumprir uma série de regulamentações exigidas pela feira.

Apresentados os interlocutores da pesquisa, exploro os procedimentos de fazer o ponto, especificamente da baiana Ciça, por ter sido a que acompanhei por mais tempo e por ser uma das mais ligadas à esfera das religiões afro-brasileiras. Eventualmente comparo seus procedimentos com os de outros casos pesquisados.

\section{A ESCOLHA DO PONTO}

Ciça informou ter iniciado a venda de acarajé na Praça XV de Novembro levada pelos santos gêmeos Cosme e Damião, os quais falaram para ela descer do ônibus em que se encontrava e ir até onde hoje é seu ponto de venda. Eles teriam guiado Ciça para esse local, mostrando por onde ir. Ela era então recém-chegada da Bahia, não conhecia a cidade, mas eles lhe mostraram o caminho, segundo a baiana. Tomou a direção que indicavam e, ao chegar na esquina, olhou para o local e declarou que seria ali seu ponto de venda de acarajé. O marido, que a acompanhava, observou: “... mas esse lugar não tem nada".

Ela foi à Prefeitura e pediu a autorização para ter o ponto. A funcionária que a atendeu concedeu uma licença provisória para Ciça trabalhar no ponto que escolheu e também comentou que naquele lugar não tinha nada. Ciça repetiu o que havia respondi- 
do ao marido: "mas agora vai ter, você vai ver". Para conseguir a autorização da Prefeitura, Ciça falou para Cosme e Damião irem na sua frente para "amansar", "preparar" a muIher responsável pela licença, com a qual iria conversar. Afirmou que conseguiu tudo o que queria, e que ainda renovou a permissão para o trabalho no local apesar das várias mudanças de governo.

Para ela, a escolha do ponto não obedeceu a uma lógica estritamente de mercado, como poderíamos supor. Em que consiste, porém, para Ciça, "fazer o ponto"? Primeiramente, Cosme e Damião indicaram o local e também teriam conseguido a autorização para ela trabalhar lá. Por se tratar de obrigação e promessa, todo ano ela oferece o "caruru de Cosme" na Praça XV de Novembro, em frente a seu ponto, atualizando com os santos gêmeos uma relação de dádiva e contradádiva (MAUSS, 2003). Além disso tem que conquistar a clientela e renovar a autorização de trabalho no local.

\section{APRENDER A FAZER ACARAJÉ}

Ciça nasceu em Maracangalha (atual São Sebastião do Passe, perto de Candeias). Lá, trabalhava na Usina Maracangalha, "limpando" cana-de-açúcar. Para ser contratada, fez promessa a Cosme e Damião. E, por sugestão de seus colegas de trabalho, ali iniciou a venda de acarajé na Festa de Cavaleiros. Ciça informou que nunca havia feito acarajé e, por isso, "não sabia que sabia fazer". A mãe não cozinhava bem, apenas costurava. A avó fazia acarajé, mas "ninguém pegou". Não aprendeu, portanto, com ninguém; "é um dom, que cada um nasce". Vale notar que sua declaração "eu não sabia que eu sabia fazer" explicita seu pertencimento a um sistema culinário, um dispositivo inconsciente, em que, de certo modo, mais do que os escolhermos, "os alimentos nos escolhem" (GONÇALVES, 2002).

Pertencer a um sistema que Ihe possibilita operar como baiana de acarajé parece ser uma forma de aprender essa culinária. Assim ela iniciou a venda, ressaltando, entretanto, que não ficou muito bom o "ponto" do acarajé. "Dar ponto" no acarajé consiste em bater a massa de modo a ficar "leve", mas sem desmanchar ao entrar em contato com o dendê fervente.

O preparo do acarajé é complexo. Em casa é feita a massa de feijão-fradinho e os complementos do acarajé (vatapá, caruru, camarão seco e salada de tomate). Cada baiana tem sua receita para esses complementos, porém, o que invariavelmente aparece em todas elas é o dendê em grandes doses. Em sua opinião e na de seus clientes, o dendê confere sabor ao acarajé, motivo pelo qual as baianas geralmente o importam da Bahia, por ser "autêntico". Na esfera da rua, a massa será batida e frita, e a baiana monta o acarajé.

Sônia compra seus ingredientes na loja Brasil Típico, que vende produtos nordes-

8. Já Ciça encomenda da Bahia o azeite, camarão e a folha de bananeira para fazer abará. tinos, localizada no Complexo da Maré, na Favela Nova Holanda, no Rio de Janeiro. ${ }^{8}$ Nesse dia, por exemplo, comprou um saco de cinco quilos de camarão defumado - há uma grande variedade de tipos de camarão, secos, salgados, frescos ou defuma- 
dos, entre outros -, um litro de dendê e uma garrafa de pimenta, que totalizaram 100 reais. O feijão-fradinho, quiabo, cebola e temperos são comprados no supermercado próximo a sua casa, no bairro da Cruz Vermelha, Centro do Rio de Janeiro. A pimenta de Sônia é feita com gengibre, pimenta-malagueta, pimenta-de-cheiro e azeite de oliva, já outras baianas utilizam o azeite de dendê.

Participei do preparo da massa do acarajé na casa de Sônia, no bairro da Cruz Vermelha. Logo ao entrar, vemos na parede, à esquerda, muitos santinhos e um desenho de Nossa Senhora da Conceição e, à direita, algumas matérias de jornal a seu respeito penduradas e emolduradas.

Logo avistei também a bacia com feijão-fradinho imerso em água, ao lado da mesa. São três etapas para o preparo da massa: a primeira é triturar o feijão e deixar de molho por algumas horas (nesse dia ficou quatro horas); a segunda etapa é peneirar para tirar a casca que envolve o grão (essa casca boia na água); a terceira é moer esses grãos formando uma massa branca compacta. Antes de deixar de molho, há a "primeira lavada", segundo Sônia. Nesse momento, escorre-se a água numa peneira para tirar as cascas que boiam. O feijão fica no fundo da bacia, e a casca sai junto com a água escorrida. Usa-se muita água em todo o processo. Ela joga fora as cascas que ficaram na peneira. Depois dessa primeira lavada, deixa o feijão de molho, durante, no mínimo, três horas.

Cilene, ajudante de Sônia, pega com uma pá de grãos o feijão e a água, passa para uma bacia menor, que leva para a pia, onde escorre a água com a casca em uma peneira. Depois, deixa a massa secar um pouco e a mói num processador. A massa fica com textura de pasta branca grossa. Coloca-a então em saco plástico, repetindo o processo várias vezes. Espera a massa esfriar no saco (pois com o processar, ela esquenta) e guarda no freezer. Nesse dia, fizeram a massa com sete quilos de feijãofradinho.

\section{MONTANDO E DESMONTANDO O TABULEIRO}

Ciça chega ao trabalho com a roupa de "baiana". ${ }^{9}$ Ela mora no bairro de São Cristóvão, na Zona Norte do Rio de Janeiro. Cozinha sozinha, em sua casa, mas recebe ajuda dos fiIhos Carlos e Luiz para vender. Chega no ponto no final da tar-
9. "Vestida de baiana": a relação mimética entre a baiana e sua roupa, também denominada de "baiana", é fundamental nesse contexto estudado. Há, de certa forma, um padrão estético seguido por elas, o que, aliás, foi parte do registro do "oficio das baianas de acarajé" e de leis locais, estabelecendo o traje típico como um quesito básico para a venda de acarajé. A roupa, o que chamam de "baiana", não é apenas emblema, um traje típico, mas objeto que desempenha papel ativo na constituição da categoria baiana de acarajé. Desse modo, as escolhas não são aleatórias, mas guiadas pelas classificações religiosas de cada elemento que a compõe. Ciça, por exemplo, usa bata, saia, anágua, sandália, torço e guias - as quais variam, mas, geralmente, são de lansã, com a cor vermelha ou marrom; e de Ogum, na cor azul. Por qual motivo exatamente essas guias e não outras? Um cliente dela explica que lansã é sua mãe guerreira, e Ogum é protetor e abre caminhos, é bom para usar no trabalho da rua. Cascudo (2001, p. 39) assim descreve a categoria baiana: “1) Indumentária que caracteriza a negra, a mestiça da capital baiana. Divulgado por meio de fotografias, desenhos, teatro 
e citações literárias, o traje tornou-se tradicional. A baiana usava chilenas nas pontas dos pés, pano da costa, saia de seda e cabeção de crivo; braço e pescoço desnudos, cheios de pulseiras e cordões de ouro; pendente da cintu$r a$, uma enorme penca de miçangas de prata. Torso branco à mouresca; bata (blusa branca engomada) em geral de algodão, às vezes de seda. Brincos de turquesa, coral, prata ou ouro. O balagandã, hoje quase desaparecido, era o principal ornamento. $O$ traje da baiana tornouse o mais típico como expressão brasileira (...)".

10. Alguns clientes afirmam que o cheiro do dendê os atrai ao ponto. $\mathrm{Na}$ pesquisa de campo, era sempre minha primeira forma de percepção da presença da baiana no local.

11. Não vou explorar aqui a diferenciação entre acarajé e acará (o acarajé servido em terreiros) por se tratar de assunto complexo e que escapa a nosso foco. Entretanto, cabe dizer que na pesquisa foi constatado que a principal diferença entre o acarajé e o acará é o "tempero", pois no "do santo" não podem usar temperos que não existiam no "tempo dos antigos", segundo alguns interlocutores, como, por exemplo, tomate e pimentão. de, para dar tempo de preparar tudo no dia, pois não gosta de levar as coisas "dormidas". Assim, passa o dia preparando as comidas para vender das 17 às 22 horas, horário de saída do trabaIho de seus clientes. Ser tudo "fresco" é o que confere qualidade ao acarajé, pois seus ingredientes são altamente perecíveis, e a massa pode fermentar se for guardada.

Os filhos Luiz ou Carlos a levam de carro. A primeira coisa que ela faz é varrer o ponto enquanto os filhos tiram o tabuleiro do depósito ao lado, um estacionamento em que ela aluga vaga para deixar o tabuleiro e as cadeiras. Juntos, então, montam o tabuleiro na esquina da Rua do Mercado.

Assim como as outras baianas pesquisadas, Ciça traz numa caixa de isopor a massa crua (em saco plástico), a cebola moída em um pote e o sal. Em panelas de alumínio traz o vatapá, o caruru e o camarão, além da salada de tomate. Coloca tudo isso dentro do tabuleiro, feito de alumínio e vidro. Montam o fogareiro ligado a um botijão de gás e sobre ele, apoiam o tacho. Acima do tabuleiro armam um guarda-sol.

Depois de montado o fogareiro, as baianas despejam o dendê no tacho e colocam uma cebola inteira para o azeite não queimar. Batem a massa com uma colher de pau, acrescentando o sal e a cebola. Usando uma colher de alumínio pegam duas vezes a massa que está na colher de pau (apoiam a colher de pau com a mão esquerda e passam a outra colher com a direita) fazendo o bolinho e o derramando devagar no azeite de dendê. O fogareiro fica sempre aceso, e elas controlam a temperatura. Nesse momento, há um forte som de fritura e muita fumaça, emanando o cheiro do dendê. ${ }^{10}$ Depois tiram o bolinho do dendê, espetando-o com uma faca e deixam escorrer um pouco o azeite antes de o secar em papel toalha.

Ciça faz primeiro os bolinhos pequenos, "do santo", que dá a alguns clientes, os "de casa", e depois faz os grandes e assim inicia a venda. Fritá-los na hora, para ficarem crocantes, é a condição sine qua nom para a boa qualidade do acarajé. Corta o acarajé, passa a pimenta ("como se fosse manteiga"), coloca o vatapá, caruru, camarão e salada com uma colher, e entrega para os clientes.

Os bolinhos pequenos são associados ao acará ${ }^{11}$ que é preparado em terreiros de candomblé, onde são ofertados a lansã e Xangô. No contexto de venda, trata-se de obrigação para começar os trabalhos, ofertada principalmente a lansã. Esse ritual 
é seguido por quase todas as baianas de acarajé, ${ }^{12}$ que são, geralmente, filhas de lansã, como Ciça, que a isso atribui o fato de trabalhar com acarajé. Ela afirma, entretanto, que não é necessário ser filha de lansã para vender acarajé, embora a ela se deva pedir permissão para o trabalho. Ela faz oferendas de acarajés para lansã num bambuzal, o que chama de "fazer um trabalho para lansã". Ciça e seus clientes explicam que lansã é a deusa dos ventos, da tempestade, da fertilidade - guerreira e dinâmica. Os clientes sempre falam que é por isso que em seu ponto há sempre vento forte.

Ao final da venda, Ciça e seus filhos guardam o tabuleiro no depósito da Rua do Mercado. Ela limpa o tacho com papel, e seu filho despeja o dendê usado em algum pote para jogar no lixo. As moedas, a figa e as cocadas (quando sobram) permanecem guardadas dentro do tabuleiro. As panelas, tacho, botijão, colher de pau e isopores são colocados no carro para ser lavados em casa, logo que chegam. Ela sempre frisa que ainda há muito trabalho para fazer em casa, ao chegar: arrumar a cozinha e lavar as panelas.

\section{A CASA E A RUA: OS CLIENTES E OS "DE CASA"}

Conquistados os clientes, eles se tornaram amigos, dispondo-se, aliás, a ajudá-la sempre que necessário. Um cliente de Ciça, por exemplo, é seu contador, outro, seu advogado. Foi por intermédio de um cliente que ela conheceu alguém da Prefeitura para ajudá-la com a autorização. Ela os chama de "o meu povo" Assim, há uma confluência entre diversas relações: inicialmente com Cosme e Damião, depois com a rua, com o ponto, com os clientes, com a esfera jurídica, entre outras. O fator fundamental, que organiza todos os seus relacionamentos, é sem dúvida sua relação com Cosme e Damião e lansã.

Ao fazer o almoço da Sexta-Feira da Paixão em sua casa, Ciça trouxe seus clientes, especificamente os "de casa", para a esfera doméstica. Nesse momento, a distinção "clientes" - pessoas classificadas como "da rua" - e os "de casa", aparece de modo ostensivo. Os clientes são aqueles que apenas comem o acarajé e vão embora; podem até conversar com ela, mas não têm ligação com nenhuma rede de relações das pessoas da barraca; são isolados. Já os "de casa" conhecem a família de Ciça, conhecem outras pessoas que frequentam também sua barraca, e geralmente ficam no ponto por mais tempo, conversando entre si e com ela. São aqueles que pedem conselhos à baiana. Na esfera dos "de casa", eles podem ser distinguidos também entre os "de casa" e os "filhos que lansã Ihe deu". O "filho", além de receber conselhos, tem mais proximidade com a esfera doméstica e com a família da baiana.

Entre os "da rua", há também diferenciação entre "clientes" e o "povo da rua" meninos e moradores de rua. $\mathrm{O}$ povo da rua está distante de sua casa, local onde resi- 
de, mas se aproxima de sua "casa de candomblé", ao associar os moradores de rua a Exu e os meninos de rua a Ibêji. São eles que protegem seu trabalho e que, portanto, devem ser respeitados. É para eles que Ciça oferece o Caruru de Cosme, como promessa por ter conseguido o ponto e a autorização de trabalho.

É importante assinalar que em todos os casos analisados há, por parte das baianas, grande respeito pelo "povo da rua", a quem oferecem acarajé e que consideram "protetor" de seu trabalho, diretamente associado à entidade Exu. "Despachar a rua" através de suas entidades protetoras é fundamental para a boa relação com o espaço público, como é o caso, por exemplo, de Nicinha, que antes da venda oferece acarajés para Exu, a fim de garantir paz. Exu é o primeiro a comer nas religiões afro-brasileiras. Ele é concebido como uma das entidades mais poderosas, capaz de abrir ou fechar caminhos.

Na esfera da rua, o espaço público transfigura-se numa espécie de casa, sendo "domesticado" através de atitudes cuidadosas em relação aos "preceitos" (as obrigações religiosas a seguir), como o preparo dos sete bolinhos de acarajé para lansã, uma vez que é primordial o respeito e a aprovação desse orixá para a venda do acarajé. No caso de Ciça, a relação de dádiva com Ibêji ou Cosme e Damião, os "meninos" que "agilizam as coisas", e com Exu, que protege a rua, é extremamente importante. Já para Nicinha, além de lansã e Ibêji, tem que agradar também Obaluaiê, o "dono da barraca" e de "sua cabeça", pois ele é seu "pai".

Desse modo, a rua aparece associada à cosmologia das religiões afro-brasileiras, guiando a relação dessas baianas com seu trabalho, com seus clientes e com a rua. Podese dizer que há uma sacralização do espaço público, em que a "comida é a essência", segundo meus interlocutores. Nesse sentido, o ponto aparece também como uma espécie de "terreiro de rua" ou, mais especificamente, de "casa de candomblé" de rua, articulando os santos e seus filhos.

A denominação do local de trabalho das baianas de acarajé como "ponto" também pode ser associada aos pontos de candomblé, que são as canções ou "toques" dos atabaques. Outra maneira de conceber o termo "ponto", e muito utilizada pelas baianas de acarajé, é o "ponto da massa". Nesse caso, dar o ponto envolve tanto a forma de fazer a massa - branca, "sem os olhinhos pretos" do feijão-fradinho - como a forma de bater, garantindo a textura necessária para ficar crocante e leve. Elas acreditam que é através dessa massa que o axé da baiana será passado.

A categoria "ponto" mostrou-se, portanto, fundamental no contexto estudado. As baianas se referem ao ponto como o local de trabalho que, como vimos, necessita de uma série de fatores para o "fazer", desde relações com o comércio em torno, com os clientes, com o povo de rua e com as entidades. A escolha do ponto pelas baianas nas esquinas também está relacionada a Exu, entidade ligada às "encruzilhadas", um local de "poder e de perigo" (Douglas, 1976), no qual as baianas "fazem o ponto". Assim, "fazer" o ponto é, nos casos estudados, ter atenção a todas as ações necessárias para a permissão e o sucesso de sua venda. 
Cada interlocutor formulou uma noção específica do que consiste ser baiana de acarajé. Para Sônia, vincula-se intimamente à ideia de etnicidade e ao movimento negro. A baiana Ciça está preocupada com suas obrigações com orixás para que seu trabalho se desenvolva satisfatoriamente. Jay busca o reconhecimento profissional e utiliza inovações da "tradição" para ressignificar seu trabalho como baiano de acarajé. Por fim, Nicinha articula grande rede de parentesco e de migrantes baianos, permanecendo com a venda de acarajé no ponto herdado de sua mãe.

Além de ressignificarem sua atividade profissional e sua relação com o acarajé, essas baianas pesquisadas nos mostraram que também estão pensado o que significou para elas o registro do "ofício das baianas de acarajé". Utilizam, atualmente, tal registro como forma de demarcação de diferença entre elas e os ambulantes, e como instrumento de reconhecimento da importância de seu trabalho para conseguir junto à Prefeitura a regularização de seus pontos de venda.

Dessa forma, pode-se dizer que a categoria jurídica patrimônio também é incorporada a seu sistema. E, mais do que artifício para obter reconhecimento e lucro, é parte de sua cosmologia, que envolve desde relações com o povo da rua, com os clientes, com a esquina, com políticas públicas (e políticos) às entidades e orixás, articulando extensa rede de trocas sociais e simbólicas.

\section{REFERÊNCIAS BIBLIOGRÁFICAS}

BECKER, Howard S. Mundos artísticos e tipos sociais. In VELHO, Gilberto. Arte e sociedade: ensaios de sociologia da arte. Rio de Janeiro: Zahar, 1977, p. 9-26.

BITAR, Nina Pinheiro. As baianas de acarajé: comida e patrimônio no Rio de Janeiro. Rio de Janeiro: Editora Aeroplano, 2011.

CASCUDO, Câmara. História da alimentação no Brasil. Belo Horizonte: Itatiaia, 1983.

. Dicionário do folclore brasileiro. São Paulo: Global, 2001.

DIAS, Maria Odila da Silva. Nas fímbrias da escravidão urbana: negras de tabuleiro e de ganho. Estudos Econômicos, n. 15. São Paulo: Instituto de Pesquisas Econômicas - IPE, 1985.

DOUGLAS, Mary. Pureza e perigo. São Paulo: Editora Perspectiva, 1976.

FONSECA JUNIOR, Eduardo. Dicionário da cultura afro-brasileira. São Paulo: Maltese, 1995.

GONÇALVES, José Reginaldo Santos. A fome e o paladar: uma perspectiva antropológica. In Alimentação e cultura popular. Rio de Janeiro: Funarte/Iphan/CNFCP, 2002.

. A fome e o paladar: a antropologia nativa de Luís da Câmara Cascudo. In Estudos Históricos. Rio de Janeiro: Centro de Pesquisa e Documentação de História Contemporânea do Brasil da Fundação Getúlio Vargas, n. 33, jan.-jun. 2004.

. Antropologia dos objetos: coleções, museus e patrimônios. Rio de Janeiro: Museu, Memória e Cidadania, 2007.

LIMA, Vivaldo da Costa. Cosme e Damião: o culto aos santos gêmeos no Brasil e na África. Salvador: Currupio, 2005.

LODY, Raul. Santo também come. Rio de Janeiro: Pallas, 1998. 
No tabuleiro da baiana tem... pelo reconhecimento do acarajé como patrimônio cultural brasileiro. In Alimentação e cultura popular. Rio de Janeiro: Funarte/ Iphan/CNFCP, 2002.

MAHIAS, M-C. Cuisine. In: Le dictionaire de l'ethnologie et de l'anthropologie, Paris: PUF, 1991.

MARTINI, Gerlaine Torres. Baianas do acarajé. A uniformização do típico em uma tradição culinária afro-brasileira. Brasília. Tese (Doutorado em Antropologia). Universidade de Brasília, Departamento de Antropologia, Programa de Pós-Graduação em Antropologia Social, 2007.

MAUSS, Marcel. Ensaio sobre a dádiva: forma e a razão da troca nas sociedades arcaicas. In Sociologia e antropologia. São Paulo: Cosac \& Naify, 2003.

MOURA, Roberto. Tia Ciata e a Pequena África do Rio de Janeiro. Rio de Janeiro: Secretaria Municipal de Cultura, 1995.

QUERINO, Manuel. A arte culinária na Bahia. Salvador: Livraria Progresso Editora, 1954.

REGISTRO E POLÍTICAS DE SALVAGUARDA PARA AS CULTURAS POPULARES. Rio de Janeiro: Funarte/Iphan/CNFCP, 2005.

ROCHA, Gilmar. O que é que a baiana tem? A etnopoética folclórica de Cecília Meireles. Revista Pós Ciências Sociais, v. 4, n. 8, São Luís, jul.-dez. 2007.

SAHLINS, Marshall. O retorno do evento, outra vez. In Cultura na prática. Rio de Janeiro: Editora UFRJ, 2004.

SCHUTZ, Alfred. Philosophy and Phenomenological Research, International Phenomenological Society. Providence, v. 5, n. 4., jun. 1945, p. 533-576.

VELLOSO, Mônica. As tias baianas tomam conta do pedaço... Espaço e identidade cultural no Rio de Janeiro. Revista Estudos Históricos, Rio de Janeiro, v. 2, n. 6, 1990.

VERDIER, Y. Pour une ethnologie culinaire. In L'homme, XI, jan.-mar., n. 1, 1969.

Nina Pinheiro Bitar é doutoranda do Programa de Pós-Graduação em Sociologia e Antropologia da UFRJ e autora do livro Baianas de acarajé: comida e patrimônio no Rio de Janeiro (Editora Aeroplano, 2011). 